\title{
Telmisartan quality control by validation of UV-spectrophotometric method
}

\author{
Dobrina Tsvetkova $^{* 1}$, Danka Obreshkova ${ }^{1,2}$, Stefka Ivanova ${ }^{1,2}$, Vladimir Yankov ${ }^{3}$, \\ Peter Atanasov ${ }^{4}$, Bozhidarka Hadjieva ${ }^{5}$ \\ ${ }^{* 1}$ Medical University-Sofia, Faculty of Pharmacy, Department of Pharmaceutical Chemistry, \\ ${ }^{2}$ Dunav Str., Sofia 1000, BULGARIA \\ ${ }^{2}$ Medical University-Plovdiv, Faculty of Pharmacy, Department of Pharmacognosy \& Pharmaceutical \\ Chemistry, 15A Vasil Aprilov Str., Plovdiv 4002, Bulgaria \\ ${ }^{3}$ Berlin Chemie, Bulgaria \\ ${ }^{4}$ Clinic of Internal Diseases UMHATEM "N. I. Pirogov"-Sofia, Bulgaria \\ ${ }^{5}$ Medical University-Plovdiv, College of Pharmacy, 15A Vasil Aprilov Str., Plovdiv 4002, Bulgaria
}

\begin{abstract}
The aim of current study was to validate spectrophotometric method with $U V$-detection for identification and determination of Telmisartan in $99.8 \%$ ethanol in respect of analytical parameters: selectivity, linearity, limit of detection (LOD), limit of quantification (LOQ), accuracy and precision (repeatability). For Telmisartan in $99.8 \%$ ethanol at $\lambda$ max $=298 \mathrm{~nm}$ for $A_{1 \% \mathrm{~cm}}^{1 \%}$ and $\varepsilon$ the obtained results for $A>0.2$ and $A<0.2$ are:
\end{abstract}

1) $A>0.2:$ at $3.10^{-6} \mathrm{~g} / \mathrm{ml} \div 1.25 .10^{-5} \mathrm{~g} / \mathrm{ml}$; $A_{1 \% \mathrm{~cm}:}^{1 \%} 725 \div 823 ; \varepsilon: 37347 \div 42335$

2) $A<0.2:$ at $2.5 .10^{-7} \mathrm{~g} / \mathrm{ml} \div 1.10^{-6} \mathrm{~g} / \mathrm{ml} ; A_{1 \mathrm{~cm}: 1201 \div 1567 ; \varepsilon: 61816 \div 80651}^{1 \%}$

Analytical parameter accuracy is represented by the degree of recovery, which in the corresponding confidence possibility suit the confidence interval: $R C_{T 60}: 100.31 \% \div 102.05 \% ; R C_{T 80}: 99.22 \% \div$ $103.18 \% ; R C_{T 100}: 93.58 \% \div 101.9 \%$. For precision is proved that all results for the quantities correspond to the relevant confidence interval: $C_{T 60}: 60.31 \mathrm{mg} \div 60.77 \mathrm{mg} ; C_{T 80}: 79.82 \mathrm{mg} \div 82.18 \mathrm{mg}$; $C_{\text {T100: }} 94.22 \mathrm{mg} \div 101.58 \mathrm{mg}$.

Keywords: Telmisartan, UV-spectrophotometry, validation, linearity.

\section{Introduction}

Arterial hypertension is an important widespread social disease [1]. Treatment of hypertension becomes successfully by the application of the developed in recent years a new class of chemical compounds - angiotensin II receptor antagonists (sartans) [2].

Telmisartan (4-((2-n-propyl-4-methyl-6-(1-methylbenzimidazol-2-yl)-benzimidazol-1-yl) methyl)biphenyl-2-carboxylic acid) (Fig. 1.) is applied for theatment of high blood pressure alone [3] or in combinations with other antihypertensive drugs: diuretic Hydrochlorothiazide [4] and calcium blocker Amlodipine [5].

Fig. 1. Chemical structure of Telmisartan

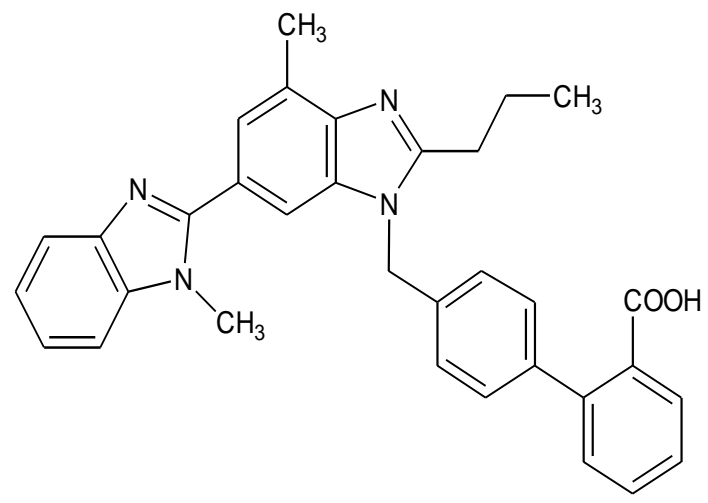


For the determination of Telmisartan in monocomponent pharmaceutical dosage forms are described the following different methods [6]:

1) High performance liquid chromatography (HPLC) with ultraviolet and mass detection [6]

2) Thin layer chromatographydensitometry [7]

3) High performance thin layer chromatography (HPTLC) $[8,9]$

4) Spectrophotometry $[6,7]$

5) Spectrofluorimetry: $\lambda$ excitation $=366$ $\mathrm{nm}$ and $\lambda$ emission $=475 \mathrm{~nm}[7,10]$

6) Electrochemical methods: linear sweep polarography by dripping mercury electrode [11]; square-wave adsorptive stripping voltammetry by hanging mercury drop electrode [12]; cathodic adsorptive stripping voltammetry [13] and cyclic voltammetry [13].

The most applied method for quantification of Telmisartan in tablets is reversed phase (RP) HPLC with UV-detection [14]-[24] at the following different chromato-graphic conditions:

1. $\lambda=229 \mathrm{~nm}, \mathrm{C}_{8}$ column, ambient temperature, mobile phase: phosphate buffer : acetonitrile $=40: 60 \mathrm{v} / \mathrm{v}$, flow rate: $0.9 \mathrm{ml} / \mathrm{min}$. [14]

2. $\lambda=225 \mathrm{~nm}, \mathrm{C}_{18}$ column, ambient temperature, mobile phase: methanol : water $=80: 20 \mathrm{v} / \mathrm{v}$, flow rate: $1.0 \mathrm{ml} / \mathrm{min}$. [15]

3. $\lambda=230 \mathrm{~nm}, \mathrm{C}_{18}$ column $(250 \mathrm{~mm} \mathrm{x}$ $4.6 \mathrm{~mm}, 5 \mu \mathrm{m})$, mobile phase: methanol : acetonitrile $=30: 70 \mathrm{v} / \mathrm{v}$, flow rate: 1 $\mathrm{ml} / \mathrm{min}$. [16]

4. $\lambda=230 \mathrm{~nm}, \mathrm{C}_{18}$ Waters column $(250 \mathrm{~mm} \mathrm{x}$ $4.6 \mathrm{~mm}, 5 \mu \mathrm{m})$, gradient mobile phase: 10 $\mathrm{mM}$ potassium dihydrogen phosphate: acetonitrile $=64: 40 \mathrm{v} / \mathrm{v}$, flow rate: 1.0 $\mathrm{ml} / \mathrm{min}$. [17]

5. $\lambda=230 \mathrm{~nm}, \mathrm{X}$ Terra column $(150 \mathrm{~mm} \mathrm{x}$ $4.6 \mathrm{~mm}, 3.5 \mu \mathrm{m})$, mobile phase: methanol : phosphate buffer $=60: 40 \mathrm{v} / \mathrm{v}$, flow rate: $0.5 \mathrm{ml} / \mathrm{min}$. [18]

6. $\lambda=243 \mathrm{~nm}, \mathrm{C}_{18}$ column $(250 \mathrm{~mm} \times 4.6$ $\mathrm{mm}, 5 \mu \mathrm{m}$ ), column temperature $45^{\circ} \mathrm{C}$, mobile phase: potassium dihydrogen phosphate $:$ acetonitrile $=60: 40 \mathrm{v} / \mathrm{v}$, flow rate: $1 \mathrm{ml} / \mathrm{min}$. [19]

7. $\lambda=254 \mathrm{~nm}, \mathrm{C}_{16}$ Supelco Discovery RP Amide column $(250 \mathrm{~mm} \times 4.6 \mathrm{~mm}, 5$ $\mu \mathrm{m}$ ), isocratic mobile phase: potassium phosphate buffer : acetonitrile $=55: 45$ $\mathrm{v} / \mathrm{v}$, flow rate: $1 \mathrm{ml} / \mathrm{min}$. [20]

8. $\lambda=256 \mathrm{~nm}$, Chromosil column, mobile phase: methanol : orthophosphoric acid : acetonitrile $=80: 5: 15 \mathrm{v} / \mathrm{v}$, flow rate: 1.5 $\mathrm{ml} / \mathrm{min}$. [21]

9. $\lambda=272 \mathrm{~nm}, \mathrm{X}$ Terra $\mathrm{C}_{18}$ column $(150 \mathrm{~mm}$ $\mathrm{x} 4.6 \mathrm{~mm}, 5 \mu \mathrm{m})$, isocratic mobile phase: $20 \mathrm{mM}$ potassium dihydrogen phosphate : acetonitrile $=40: 60 \mathrm{v} / \mathrm{v}$, flow rate: 0.8 $\mathrm{ml} / \mathrm{min}$. [22]

10. $\lambda=295 \mathrm{~nm}$, Luna $\mathrm{C}_{1}$ column, mobile phase: phosphate buffer : acetonitrile $=60$ : $40 \mathrm{v} / \mathrm{v}$, flow rate: $1 \mathrm{ml} / \mathrm{min}$. [23]

11. $\lambda=296 \mathrm{~nm}$, Phenomenex column, mobile phase: $10 \mathrm{mM}$ potassium dihydrogen phosphate buffer: methanol $=20: 80 \mathrm{v} / \mathrm{v}$, flow rate: $0.8 \mathrm{ml} / \mathrm{min}$. [24].

Ultra High Performance Liquid Chromatographic method (RP-UHPLC) has been developed for the estimation of Telmisartan in pharmaceutical dosage form by using of chromatographic system: $\lambda=290 \mathrm{~nm}, \mathrm{C}_{18}$ Waters Aquity BEH column (100 $\mathrm{mm} \times 2.1 \mathrm{~mm}, 1.7 \mu$ ), gradient mode: A mobile phase: $10 \mathrm{mM}$ ammonium acetate : acetonitrile in the ratio $90: 10 \mathrm{v} / \mathrm{v}$; and $\mathrm{B}$ mobile phase: acetonitrile, flow rate: $0.3 \mathrm{ml} / \mathrm{min}$. [25]. In other reported RP-UHPLC method Telmisartan is assayed at $\lambda=290 \mathrm{~nm}$ with a Poroshell 120EC$\mathrm{C}_{18}$ column $(50 \mathrm{~mm} \times 4.6 \mathrm{~mm}, 2.7 \mu \mathrm{m})$, column 
temperature: $25{ }^{\circ} \mathrm{C}$, mobile phase: acetonitrile: 50 $\mathrm{mM}$ ammonium acetate buffer $=45: 55 \mathrm{v} / \mathrm{v}$, flow rate: $0.5 \mathrm{ml} / \mathrm{min}$. [26].

For quantity analysis of Telmisartan in tablets are reported the following spectrophotometric methods:

I) UV-spectrophotometry, based on the measurement of absorbance at:

1) $\lambda=234 \mathrm{~nm}$ in $0.1 \mathrm{~N} \mathrm{NaOH}$ : distilled water $=20: 80 \mathrm{v} / \mathrm{v}$ [27];

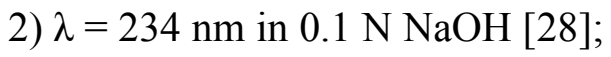
3) $\lambda=240 \mathrm{~nm}$ in $95 \%$ ethanol : 0.1 $\mathrm{N} \mathrm{NaHCO}_{3}=60: 40 \mathrm{v} / \mathrm{v}$ [29]; 4) $\lambda$ $=295 \mathrm{~nm}$ in $0.1 \mathrm{~N} \mathrm{NaOH} \mathrm{[30];} \mathrm{5)} \lambda$ $=295 \mathrm{~nm}$ in methanol [31]; 6) $\lambda=$ $298 \mathrm{~nm}$ in methanol : water $=90$ : $10 \mathrm{v} / \mathrm{v}$ [32]; 7) $\lambda=315 \mathrm{~nm}$ in $10 \mathrm{M}$ urea [33]

II) First derivative spectrophotometry at $\lambda=$ $241.6 \mathrm{~nm}$ [7]

III) Ratio derivative spectrophotometry at $\lambda=$ $242.7 \mathrm{~nm}$ [7]

IV)Zero order spectrophotometry at $\lambda=234$ $\mathrm{nm}$ [28]

V) Difference spectrophotometry: by calculation the difference between the absorbance values of the solution in 0.01 $\mathrm{M} \mathrm{NaOH}$ at $\lambda=295 \mathrm{~nm}$ and in $0.01 \mathrm{~N}$ $\mathrm{HNO}_{3}$ at $\lambda=327 \mathrm{~nm}$ [34]

VI) Spectrophotometry in visible area after derivativative reaction for Telmisartan with different reagents: bromothymol blue $(\lambda=412 \mathrm{~nm})$ [35]; 2, 5-dichloro, 3, 6dihydroxy, 1 , 4-benzoquinone $(\lambda=460$ $\mathrm{nm})$ [36]; orange-G. $(\lambda=482 \mathrm{~nm})$ [35]; azurin-B dye $(\lambda=508 \mathrm{~nm})$ [37]; eriochrome black-T $(\lambda=510 \mathrm{~nm})$ [38], wool fat blue $(\lambda=585 \mathrm{~nm})$ [36]; congo-red $(\lambda=593 \mathrm{~nm})[39]$.

For Telmisartan in tablets the reported UVspectrophotometric methods are based on the measurement of absorbance in $0.1 \mathrm{~N} \mathrm{NaOH}$ : distilled water $=20: 80 \mathrm{v} / \mathrm{v}$ [27], $0.1 \mathrm{~N} \mathrm{NaOH}[28$,
30]; $95 \%$ ethanol: $0.1 \mathrm{~N} \mathrm{NaHCO} 3=60: 40 \mathrm{v} / \mathrm{v}$ [29], methanol [31], methanol: water $=90: 10 \mathrm{v} / \mathrm{v}$ [32] and $10 \mathrm{M}$ urea [33].

The aim of current study was the determination of Telmisartan in dosage preparations by UVspectrophoto-metry in $99.8 \%$ ethanol.

\section{MATERIALS}

\section{Reference standard: Telmisartan \\ II. Reagents: $99.8 \%$ ethanol}

\section{METHODS - UV-spectrophotometry}

I. Preparation of solutions of reference standard Telmisartan in $99.8 \%$ ethanol for validation of analytical parameter linearity.

An accurately weighed quantity of reference standard Telmisartan: $125 \mathrm{mg}, 100 \mathrm{mg}, 90 \mathrm{mg}, 80$ $\mathrm{mg}, 50 \mathrm{mg}, 40 \mathrm{mg}, 30 \mathrm{mg}, 10 \mathrm{mg}, 5 \mathrm{mg}, 2.5 \mathrm{mg}$ was dissolved in $99.8 \%$ ethanol in a volumetric flask of $100.0 \mathrm{ml}$. An aliquot part of $1.0 \mathrm{ml}$ from all of the obtained samples was diluted with with the same solvent to $100.0 \mathrm{ml}$.

The resulting solutions have a concentration of Telmisartan respectively: $1.25 .10^{-5} \mathrm{~g} / \mathrm{ml} ; 1.10^{-5}$ $\mathrm{g} / \mathrm{ml} ; 9.10^{-6} \mathrm{~g} / \mathrm{ml} ; 8.10^{-6} \mathrm{~g} / \mathrm{ml} ; 5.10^{-6} \mathrm{~g} / \mathrm{ml} ; 4.10^{-6}$ $\mathrm{g} / \mathrm{ml} ; 3.10^{-6} \mathrm{~g} / \mathrm{ml} ; 1.10^{-6} \mathrm{~g} / \mathrm{ml} ; 5.10^{-7} \mathrm{~g} / \mathrm{ml} ; 2.5 .10^{-7}$ $\mathrm{g} / \mathrm{ml}$ and were analysed at $\lambda=298 \mathrm{~nm}$ against $99.8 \%$ ethanol.

II. Preparation of solutions of reference standard Telmisartan for the validation of the method in terms of analytical parameters accuracy and precision (repeatability).

An accurately weighed quantity of reference standard Telmisartan: $60 \mathrm{mg}, 80 \mathrm{mg}$ and $100 \mathrm{mg}$ was dissolved in $99.8 \%$ ethanol in volumetric flasks $100.0 \mathrm{ml}$. Aliquot parts of $1.0 \mathrm{ml}$ of these solutions are diluted with the same $99.8 \%$ ethanol to $100.0 \mathrm{ml}$ to obtain solutions with concentration of Telmisartan respectively: $6.10^{-6} \mathrm{~g} / \mathrm{ml} ; 8.10^{-6}$ $\mathrm{g} / \mathrm{ml} ; 1.10^{-5} \mathrm{~g} / \mathrm{ml}$. 
The absorbances of last solutions were measured at $\lambda \max =298 \mathrm{~nm}$, using as blank solution $99.8 \%$ ethanol.

\section{Preparation of model mixtures of reference} standard Telmisartan for validation of the method in terms of analytical parameters accuracy and precision (repeatability).

Three equal homogenous model mixtures were prepared from the most used in tablets supplement starch by adding of reference standard Telmisartan, equivalent to: $75 \%$ : $60 \mathrm{mg}$ (T60), $100 \%: 80 \mathrm{mg}$ (T80), $125 \%: 100 \mathrm{mg}$ (T100) of its concentration in tablets $(80 \mathrm{mg})$.

For every mixtire were prepared 3 samples and were dissolved in $99.8 \%$ ethanol in volumetric flasks of $100.0 \mathrm{ml}$. Aliquot parts of $1.0 \mathrm{ml}$ of every of 9 resulting solutions were diluted with the same solvent to $100.0 \mathrm{ml}$.
Every sample was analysed separately by UVspectrophotometric method by measuring of the absorbance at $\lambda=298 \mathrm{~nm}$, using as blank solution $99.8 \%$ ethanol.

\section{RESULTS AND DISCUSSION}

I. Estimation of specific $\left(\mathrm{A}^{1 \%} 1 \mathrm{~cm}\right)$ and molar $(\varepsilon)$ absorbances of solutions of reference standard Telmisartan in $99.8 \%$ ethanol at $\lambda \max =298$ nm.

Data for the values of specific $\left(\mathrm{A}^{1 \%}{ }_{1 \mathrm{~cm}}\right)$ and molar $(\varepsilon)$ absorbances of solutions of reference standard Telmisartan in $99.8 \%$ ethanol at $\lambda \max =298 \mathrm{~nm}$ in concentration interval $2.5 .10^{-7} \mathrm{~g} / \mathrm{ml} \div 1.25 .10^{-5}$ $\mathrm{g} / \mathrm{ml}$ were calculated and presented on Table 1 .

Table 1. Specific $\left(\mathrm{A}^{1 \%}{ }_{1 \mathrm{~cm}}\right)$ and molar $(\varepsilon)$ absorbances of reference standard Telmisartan $\lambda=298 \mathrm{~nm}$.

\begin{tabular}{|c|c|c|c|c|}
\hline $\mathbf{C}[\mathbf{g} / \mathbf{1 0 0} \mathbf{~ m l}]$ & $\mathbf{A}$ & $\mathbf{A}^{\mathbf{1 \%}} \mathbf{1 \mathbf { c m }}$ & $\mathbf{C}[\mathbf{m o l} / \mathbf{l}]$ & $\mathbf{\varepsilon}$ \\
\hline $2.5 \cdot 10^{-5}$ & 0.03918 & 1567 & $4.85 .10^{-7}$ & 80651 \\
\hline $5.10^{-5}$ & 0.06985 & 1397 & $9.71 .10^{-7}$ & 71892 \\
\hline $1.10^{-6}$ & 0.12012 & 1201 & $1.94 .10^{-6}$ & 61816 \\
\hline $3.10^{-4}$ & 0.23885 & 796 & $5.83 .10^{-6}$ & 40972 \\
\hline $4.10^{-4}$ & 0.32906 & 823 & $7.77 .10^{-6}$ & 42335 \\
\hline $5.10^{-4}$ & 0.36391 & 728 & $9.72 .10^{-6}$ & 37455 \\
\hline $8.10^{-4}$ & 0.58446 & 731 & $1.55 .10^{-5}$ & 37597 \\
\hline $9.10^{-4}$ & 0.65706 & 730 & $1.75 .10^{-5}$ & 37570 \\
\hline $1.10^{-3}$ & 0.76378 & 764 & $1.94 .10^{-5}$ & 39305 \\
\hline $1.25 .10^{-3}$ & 0.90715 & 725 & $2.43 .10^{-5}$ & 37347 \\
\hline
\end{tabular}

II. Validation of UV-spectrophotometric method for the analytical parameters: selectivity, linearity, limit of detection (LOD), limit of quantification (LOQ), accuracy, precision (repeatability) [41].

\section{1) Selectivity}

For the estimatiton of analytical parameter selectivity in the same manner like solutions of reference standard Telmisartan, "placebo" solution was prepared. In "Placebo" solution was included the used in tablets supplement starch without the active ingredient Telmartan. UVspectrophotometric method was applied for "placebo" solution. The obtained experimental results demonstrated that in UV-spectra of "placebo" solution was not observed the measured absorption at the specific for Telmisartan wavelength $\lambda=298 \mathrm{~nm}$. By this fact the selectivity of the proposed UVspectrophotometric method was proved. 
2) Linearity: application of method of linear regression analysis.

On Fig. 2. Are illustrated spectra of solutions of reference standard Telmisartan in $99.8 \%$ ethanol

Fig. 2. Spectra of solutions of reference standard Telmisartan in $99.8 \%$ - estimation of analytical parameter linearity

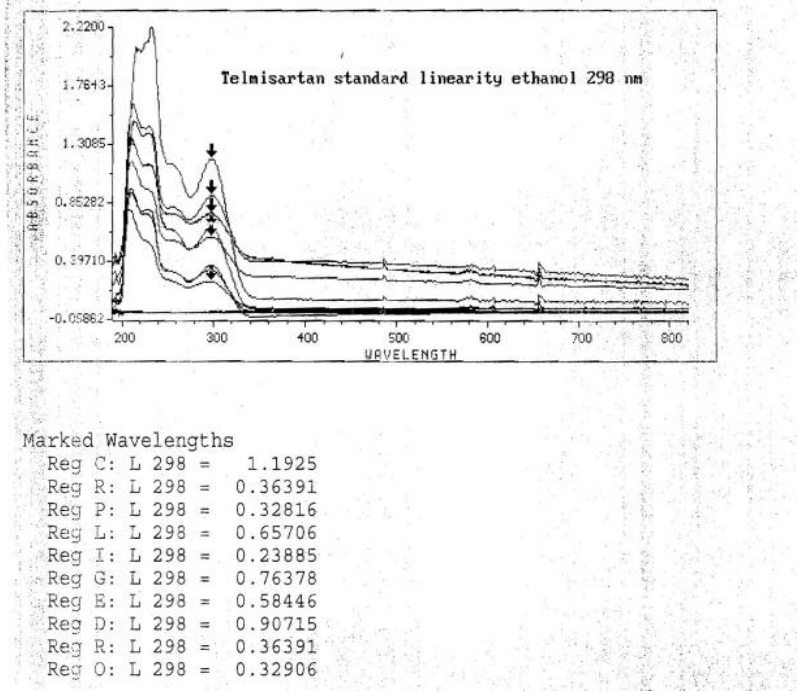

Linearity is the range within the signal from the detector remains in linear dependency from the concentration of analyte [40]. For the estimation of analytical parameter linearity for Telmisartan for absorbance values: $\mathrm{A}>0.2$ and $\mathrm{A}<0.2$, was searched the dependence of absorbance from concentration at the absorption maximum $\lambda$ max $=$ $298 \mathrm{~nm}$. For this purpose from reference standard Telmisartan were prepared a series of solutions with decreasing concentrations and were analyzed by the written UV-spectrophotometric method. For every concentration (C) in $\mathrm{g} / \mathrm{ml}$ the respective value of the absorbance (A) in absorption units (AU) at $\lambda \max =298 \mathrm{~nm}$ was measured. The experimental results were subjected to a linear regression analysis. The presented regression equations: $y=a . x+b$ are: $y=70980 . x+0.02$ for $\mathrm{A}>0.2$ and $\mathrm{y}=106866 . \mathrm{x}+0.014$ for $\mathrm{A}<0.2$ and show the proportional accordance $A=f(C)$ in linear concentration ranges: $1.10^{-6} \mathrm{~g} / \mathrm{ml} \div 2.7 .10^{-5}$ $\mathrm{g} / \mathrm{ml}$ for $\mathrm{A}>0.2$ and $1.10^{-6} \mathrm{~g} / \mathrm{ml} \div 2.5 .10^{-7} \mathrm{~g} / \mathrm{ml}$ for $\mathrm{A}<0.2$, where the Buge-Lambert-Beere law is valid. The correlation coefficients $R^{2}$ were calculated. Parameter linearity, respectively at A > 2 and $\mathrm{A}<0.2$ is illustrated by the calibration curves, which are shown on Fig. 3. $(\mathrm{A}>0.2)$ and Fig. 4. $(\mathrm{A}<0.2$. $)$.

Fig. 3. Linearity for Telmisartan in $99.8 \%$ ethanol for $\mathrm{A}>0.2$.

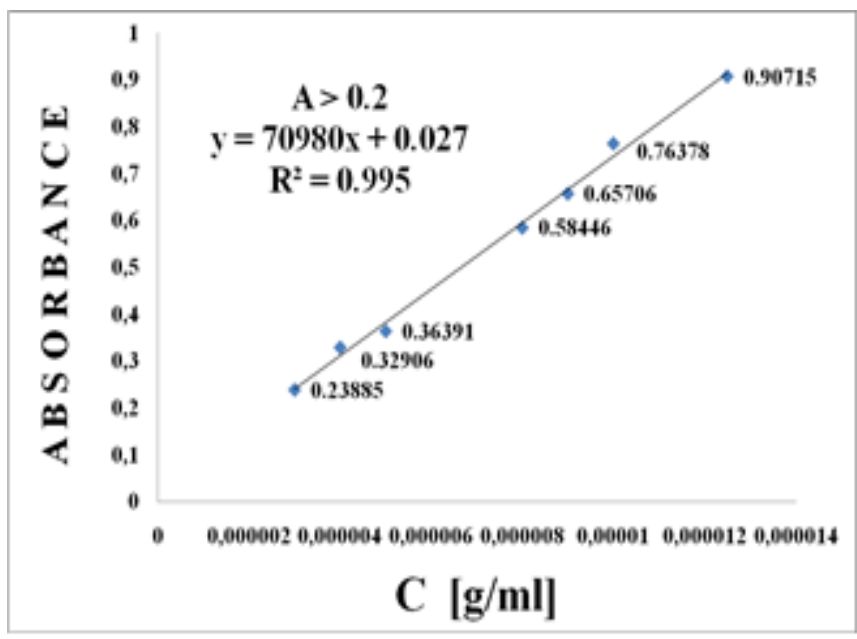

Fig. 4. Linearity for Telmisartan in $99.8 \%$ ethanol for $\mathrm{A}<0.2$.

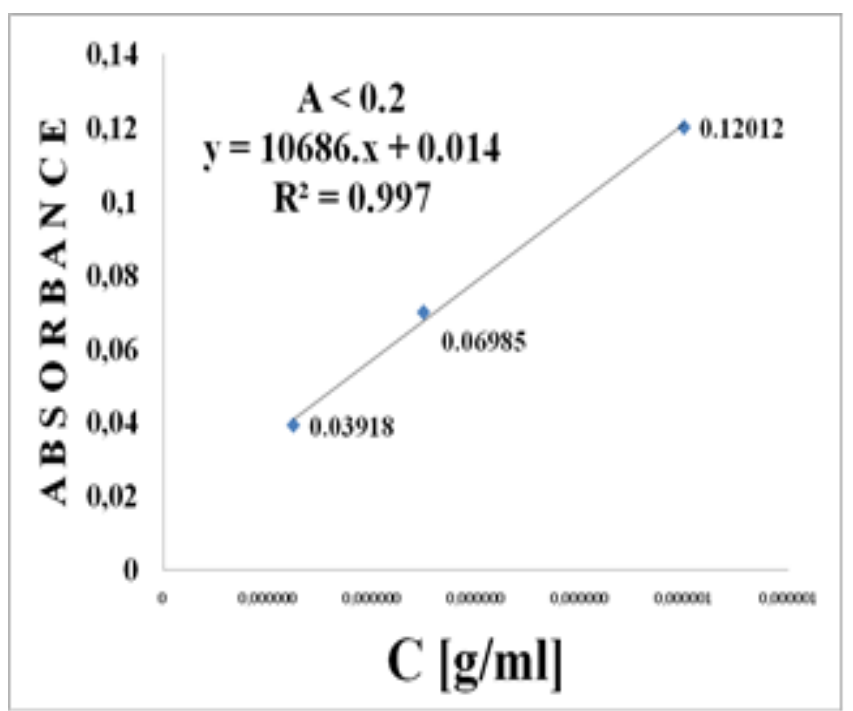

On Table 2. Are inclused parameters of regression equations for Telmisartan for $\mathrm{A}>0.2$ and $\mathrm{A}<0.2$, where: $\lambda \max [\mathrm{nm}]$ - absorbance maximum; $C$ $[\mathrm{g} / \mathrm{ml}]$ - concentration range; $\mathrm{y}=\mathrm{a} . \mathrm{x}+\mathrm{b}-$ regression equation; $\mathrm{R}^{2}$ - coefficient of linear regression. 
Table 2. Parameters of regression equstions for Telmisartan.

\begin{tabular}{|c|c|c|c|}
\hline $\mathbf{N}:$ & Parameters & $\mathbf{A}>\mathbf{0 . 2}$ & $\mathbf{A}<\mathbf{0 . 2}$ \\
\hline 1. & $\lambda \max (\mathrm{nm})$ & 298 & 298 \\
\hline 2. & Linear range $(\mathrm{g} / \mathrm{ml})$ & $1.10^{-6} \div 2.7 .10^{-5}$ & $1.10^{-6} \div 2.5 .10^{-7}$ \\
\hline 3. & Regression equation & $70980 . \mathrm{x}+0.02$ & $106866 . \mathrm{x}+0.014$ \\
\hline 4. & Slope (a) & 70980 & 106866 \\
\hline 6. & Intersept (b) & 0.02 & 0.014 \\
\hline 7. & Correlation coefficient $\left(\mathrm{R}^{2}\right)$ & 0.9956 & 0.9974 \\
\hline
\end{tabular}

3) Limit of detection (LOD) and limit of quantitation (LOQ).

For the estimation of analytical parameters limit detection (LOD) and limit of quantitation (LOQ), the received at the absorption maximum $\lambda \max =$ $298 \mathrm{~nm}$ experimental results for absorbance values $\mathrm{A}<0.2$, are subjected to linear regression analysis. LOD $[\mathrm{g} / \mathrm{ml}]$ and LOQ $[\mathrm{g} / \mathrm{ml}]$ are based on regression equation by application of the method RMSE - root mean square error (Table. 3). In this methid for the determination of LOD and LOQ, from the regression equation 106866. $\mathrm{x}$ +0.014 are calculated the predicted absorbances (Ap). For each sample were calcuated defined error $\mathrm{E}=\left|\mathrm{A}_{\mathrm{p}}-\mathrm{A}\right|, \mathrm{E}^{2}=\left[\left|\mathrm{A}_{\mathrm{p}}-\mathrm{A}\right|\right]^{2}, \mathrm{E} 1=\frac{\sum \mathrm{E} 2}{n-2}$; RMSE $=\sqrt{E 1} ;$ LOD $=3$. RMSE $/ \mathrm{a} ; \quad$ LOQ $=$ 10.RMSE/a (Table 3.) [40].

Table 3. RMSE-method for LOD и LOQ for Telmisartan at $\mathrm{A}<0.2$.

\begin{tabular}{|c|c|c|c|c|}
\hline $\mathrm{C}[\mathrm{g} / \mathrm{ml}]$ & $\mathbf{A}$ & Ap & $|\mathbf{A}-\mathbf{A p}|$ & $\mathbf{E}^{2}=\left[\left|\mathbf{A}_{\mathbf{p}}-\mathbf{A}\right|\right]^{2}$ \\
\hline $1.10^{-6}$ & 0.12012 & 0.12087 & 0.00075 & $5.62 .10^{-7}$ \\
\hline $5.10^{-7}$ & 0.06985 & 0.06743 & 0.00242 & $5.86 .10^{-6}$ \\
\hline $2.5 .10^{-7}$ & 0.03918 & 0.04072 & 0.00154 & $2.37 .10^{-6}$ \\
\hline $\mathrm{E} 1=\frac{\sum \mathrm{E} 2}{n-2}$ & \multicolumn{4}{|c|}{$8.79 .10^{-6}$} \\
\hline $\mathrm{RMSE}=\sqrt{E 1}$ & \multicolumn{4}{|c|}{$2.96 .10^{-3}$} \\
\hline LOD & \multicolumn{4}{|c|}{$8.3 .10^{-8} \mathrm{~g} / \mathrm{ml}$} \\
\hline LOQ & \multicolumn{4}{|c|}{$2.77 .10^{-7} \mathrm{~g} / \mathrm{ml}$} \\
\hline
\end{tabular}

\section{4) Accuracy}

Analytical parameter accuracy is the degree of correspondence between the obtained average result of repeated analysis and the actual value [40].
On Table 4. Are presented data for added content of reference standard Telmisartan in 3 samples for 3 model mixtures: T60 (60 mg, $75 \%$ ) (Average weight $=0.36 \mathrm{~g}) ; \mathrm{T} 80(80 \mathrm{mg}, 100 \%)($ Average weight $=0.48 \mathrm{~g})$; T100 (100 mg, $125 \%)($ Average weight $=0.6 \mathrm{~g}$ ). 
Table. 4. Added content of reference standard Telmisartan in model mixtures.

\begin{tabular}{|c|c|c|c|c|c|}
\hline $\begin{array}{c}\text { Added } \\
\text { T60 }[\mathbf{m g}]\end{array}$ & $\begin{array}{c}\text { Weighed T60 } \\
{[\mathbf{g}]}\end{array}$ & $\begin{array}{c}\text { Added } \\
\mathbf{T 8 0}[\mathbf{m g}]\end{array}$ & $\begin{array}{c}\text { Weighed } \\
\mathbf{T 8 0}[\mathbf{g}]\end{array}$ & $\begin{array}{c}\text { AddeT100 } \\
{[\mathbf{m g}]}\end{array}$ & $\begin{array}{c}\text { Weighed } \\
\mathbf{T 1 0 0}[\mathbf{g}]\end{array}$ \\
\hline 60.25 & 0.3615 & 80.33 & 0.482 & 99.8 & 0.5988 \\
\hline 60.06 & 0.3604 & 80.08 & 0.4805 & 100.2 & 0.6012 \\
\hline 59.77 & 0.3586 & 79.72 & 0.4783 & 100.5 & 0.603 \\
\hline
\end{tabular}

On Table. 5. Are included the results for absorbances at $\lambda=298 \mathrm{~nm}$ of model mixtures of reference standard Telmisartan in $99.8 \%$ ethanol:

$\mathrm{A}_{\mathrm{T} 60}(\mathrm{Ast}=0.42795) ; \mathrm{A}_{\mathrm{T} 80}(\mathrm{Ast}=0.58446) ; \mathrm{A}_{\mathrm{T} 100}$ (Ast $=0.76378)$ and Chauvenet's criterion for absorbances: $\mathrm{U} \mathrm{A}_{\mathrm{T} 60}, \mathrm{U} \mathrm{A}_{\mathrm{T} 80}, \mathrm{U} \mathrm{A}_{\mathrm{T} 100 \text {. }}$

Table. 5. Absorbances and Chauvenet's criterion for absorbances at $\lambda=298 \mathrm{~nm}$ of model mixtures with Telmisartan in $99.8 \%$ ethanol.

\begin{tabular}{|c|c|c|c|c|c|c|}
\hline $\mathbf{N}:$ & $\mathbf{A}_{\text {T60 }}$ & $\mathbf{U ~ A}_{\text {T60 }}$ & $\mathbf{A}_{\text {T80 }}$ & $\mathbf{U ~ A ~}_{\text {T80 }}$ & $\mathbf{A}_{\text {T100 }}$ & $\mathbf{U ~ A ~}_{\text {T100 }}$ \\
\hline 1. & 0.43401 & 1.01 & 0.58763 & 1.12 & 0.76794 & 1.19 \\
\hline 2. & 0.43103 & 0.48 & 0.59521 & 0.78 & 0.73941 & 0.59 \\
\hline 3. & 0.43092 & 0.54 & 0.59344 & 0.34 & 0.73935 & 0.6 \\
\hline $\bar{X}$ & 0.43199 & & 0.59209 & & 0.74890 & \\
\hline SD & 0.002 & & 0.004 & & 0.02 & \\
\hline RSD [\%] & 0.46 & & 0.68 & & 2.14 & \\
\hline
\end{tabular}

For the estimation of accuracy of model mixtures with reference standard Telmisartan in $99.8 \%$ ethanol are presented the results for: obtained content of Telmisartan: $\mathrm{C}_{\mathrm{T} 60}, \mathrm{C}_{\mathrm{T} 80}, \mathrm{C}_{\mathrm{T} 100}$, after application of $\mathrm{UV}$-spectrophotometric method (Table 6.), degree of recovery: $\mathrm{R}_{\mathrm{T} 60} ; \mathrm{R}_{\mathrm{T} 80} ; \mathrm{R}$
$\mathrm{C}_{\mathrm{T} 100}$ (Table 7.) $\bar{X}$ - mean arithmetic error; $\mathrm{SD}-$ standard deviation; RSD - relative standard deviation (\%); $\mathrm{S} \bar{X}-$ mean square error; $\bar{X} \pm \mathrm{t} . \mathrm{S}$ $\bar{X}=\bar{X}-$ t.S $\bar{X} \div \bar{X}+$ t.S $\bar{X}-$ confidence interval; $\mathrm{E}(\%)$ - relative error. $\mathrm{P}$ - Confidence possibility is $95 \%$ and $t-$ coefficient of Student is 2.57 .

Table. 6. Obtained content of Telmisartan in model mixtures.

\begin{tabular}{|c|c|c|c|}
\hline $\mathbf{N :}$ & $\mathbf{C}_{\mathbf{T 6 0}}[\mathbf{m g}]$ & $\mathbf{C}_{\mathbf{T 8 0}}[\mathbf{m g}]$ & $\mathbf{C}_{\mathbf{T 1 0 0}}[\mathbf{m g}]$ \\
\hline 1. & 60.6 & 80.1 & 100.75 \\
\hline 2. & 60.36 & 81.39 & 96.62 \\
\hline 3. & 60.65 & 81.52 & 96.32 \\
\hline $\bar{X} \pm \mathrm{SD}$ & $60.54 \pm 0.16$ & $0.0 \pm 0.79$ & $97.90 \pm 2.48$ \\
\hline $\mathrm{SD}$ & 0.16 & 0.98 & 2.48 \\
\hline $\mathrm{RSD}[\%]$ & 0.26 & 0.46 & 2.53 \\
\hline $\mathrm{S}-\bar{X}$ & 0.09 & 1.18 & 3.68 \\
\hline $\mathrm{t.S} \bar{X}$ & 0.23 & $79.82 \div 82.18$ & $94.22 \div 101.58$ \\
\hline $\bar{X} \pm \mathrm{t.S} \bar{X}$ & $60.31 \div 60.77$ & 0.57 & 1.46 \\
\hline $\mathrm{E}[\%]$ & 0.15 & & \\
\hline
\end{tabular}


Table. 7. Degree of recovery for Telmisartan in model mixtures.

\begin{tabular}{|c|c|c|c|}
\hline $\mathbf{N}:$ & $\mathrm{R} \mathrm{C}_{\mathrm{T} 60}[\%]$ & $\mathrm{R} \mathrm{C}_{\mathrm{T80}}[\%]$ & $\mathrm{R} \mathrm{C}_{\mathrm{T} 100}[\%]$ \\
\hline 1. & 101.58 & 99.71 & 100.95 \\
\hline 2. & 100.5 & 101.64 & 96.43 \\
\hline 3. & 101.47 & 102.26 & 95.84 \\
\hline \multicolumn{4}{|l|}{$\bar{X} \pm \mathrm{SD}$} \\
\hline $\bar{R}[\%] \pm \mathrm{RSD}[\%]$ & $101.18 \pm 0.58$ & $101.2 \pm 1.31$ & $97.74 \pm 2.86$ \\
\hline $\mathrm{SD}$ & 0.59 & 1.33 & 2.8 \\
\hline $\operatorname{RSD}[\%]$ & 0.58 & 1.31 & 2.86 \\
\hline$S \bar{x}$ & 0.34 & 0.77 & 1.62 \\
\hline $\operatorname{t.S} X$ & 0.87 & 1.98 & 4.16 \\
\hline $\bar{X} \pm$ t.S $X$ & $100.31 \div 102.05$ & $99.22 \div 103.18$ & $93.58 \div 101.9$ \\
\hline $\mathrm{E}[\%]$ & 0.86 & 0.76 & 1.66 \\
\hline
\end{tabular}

For the assessment of the need for the removal of sharply differing data is used the criterion of Chauvent. The obtained data for Chauvenet's criterion for absorbanses (Table 5.) and for the quantities (Table 6.) for Telmisartan are lower than the maximum permissible value for this criterion $(\mathrm{U}=1.68 ; \mathrm{N}=3)$. By this fact is demonstrated that the results correspond to the requirements for the criterion in the analysis of 3 samples and there is no need to remove any of the received data [40].

Analytical parameter accuracy for UV-method was established by the degree of recovery at $75 \%$ $(60 \mathrm{mg}) 100 \%(80 \mathrm{mg}) ; 125 \%(100 \mathrm{mg})$ of the test concentration as per ICH guidelines [41]. The recovery study was performed 3 times at each level. Accuracy is represented by the degree of recovery $\mathrm{R}[\%] \pm \mathrm{RSD}(\%): \mathrm{R} \mathrm{C}_{\mathrm{T} 60}: 101.18 \% \pm$ $0.58 \%$; $\mathrm{R} \mathrm{C}_{\mathrm{T} 80}: 101.2 \% \pm 1.31 \% \mathrm{R} \mathrm{C}_{\mathrm{T} 100}: 97.74$ $\% \pm 2.86 \%$. The results show that at the used confidence possibility all experimental data for $\mathrm{R}$ correspond to the respective interval: $\mathrm{R}_{\mathrm{T} 60}$ : $100.31 \% \div 102.05 \%$; $\mathrm{R} \mathrm{C}_{\mathrm{T} 80}: 99.22 \% \div 103.18$ $\%$; $\mathrm{R} \mathrm{C}_{\mathrm{T} 100}: 93.58 \% \div 101.9 \%$.

\section{5) Precision (Repeatability)}

By an analytical parameter precision (repeatability) is expressed the degree of closenest of the results of measurements of one and the same value (absorbance) in the analysis of samples taken from one homogeneous sample at applcation of the same methodology at wthe same conditions for a short time [41]. Repeatability is characterized by the uncertainty of the result, which includes standard deviation (SD), relative standard deviation (RSD) and confidential interval $(\bar{X} \pm$ t.S $\bar{X}=\bar{X}-$ t.S $\bar{X} \div \bar{X}+\mathrm{t} . \mathrm{S} \bar{X})$. For model mixtures is proved that at the corresponding confidence possibility, all results for the obtained quantities of Telmisartan (Table 6.) in $99.8 \%$ ethanol from the analysis of three samples from each of the three model mixtures, suit the appropriate confidence interval [40]: $\mathrm{C}_{\mathrm{T} 60}: 60.31$ $\mathrm{mg} \div 60.77 \mathrm{mg}(\mathrm{SD}=0.16 ; \mathrm{RSD}=0.26) ; \mathrm{C}_{\mathrm{T} 80}$ : $79.82 \mathrm{mg} \div 82.18 \mathrm{mg}(\mathrm{SD}=0.79 ; \mathrm{RSD}=0.98)$; $\mathrm{C}_{\mathrm{T} 100}: 94.22 \mathrm{mg} \div 101.58 \mathrm{mg}(\mathrm{SD}=2.48 ; \mathrm{RSD}=$ 2.53). 


\section{CONCLUSION}

For Telmisartan in $99.8 \%$ ethanol at $\lambda \max =298$ $\mathrm{nm}$ for $\mathrm{A}^{1 \%}$ cm and $\varepsilon$ the obtained results for $\mathrm{A}>$ 0.2 and $\mathrm{A}<0.2$ are: 1$) \mathrm{A}>0.2$ : at $3.10^{-6} \mathrm{~g} / \mathrm{ml} \div$ $1.25 .10^{-5} \mathrm{~g} / \mathrm{ml} ; \quad A^{1 \%}{ }_{1 \mathrm{~cm}}: 725 \div 823 ; \varepsilon: 37347 \div$ 42335; 2) $\mathrm{A}<0.2$ : at $2.5 .10^{-7} \mathrm{~g} / \mathrm{ml} \div 1.10^{-6} \mathrm{~g} / \mathrm{ml}$; $\mathrm{A}^{1 \%}{ }_{1 \mathrm{~cm}}: 1201 \div 1567$; $\varepsilon: 61816 \div 80651$. UVspectrophotometric method for determination of Telmisartan in $99.8 \%$ ethanol at $\lambda \max =298 \mathrm{~nm}$ by method of external standard is validated by the analytical parameters: selectivity, linearity, LOD, LOQ, accuracy, precision. Accuracy is represented by the degree of recovery, which suit in confidence interval: $\mathrm{R} \mathrm{C}_{\mathrm{T} 60}: 100.31 \div 102.05 ; \mathrm{R}$ $\mathrm{C}_{\mathrm{T} 80}: 99.22 \div 103.18 ; \mathrm{R} \mathrm{C}_{\mathrm{T} 100}: 93.58 \div 101.9$. For precision is proved that all results for the quantities suit relevant interval: $\mathrm{C}_{\mathrm{T} 60}: 60.31 \mathrm{mg} \div$ $60.77 \mathrm{mg} ; \mathrm{C}_{\mathrm{T} 80}: 79.82 \mathrm{mg} \div 82.18 \mathrm{mg} ; \mathrm{C}_{\mathrm{T} 100}$ : $94.22 \mathrm{mg} \div 101.58 \mathrm{mg}$.

\section{REFERENCES}

1) D.A. Taylor, A.A. Abdel-Rahman, "Novel strategies and targets for the management of hypertension", Adv. Pharmacol., 57 (1), pp. 291-345, 2009.

2) K.C. Ferdinand, C. Taylor, "The management of hyper-tension with angiotensin receptor blockers in special popula-tions", Clin. Cornerstone, 9 (Suppl. 3), pp. S5-S17, 2009.

3) M.A.Weber, "Telmisartan in high-risk cardiovascular pa-tients", Amer. J. Cardiol., 105 (1), Suppl. 1, pp. 36A-43A, 2010.

4) R. Fogari, A. Zoppi, A. Mugellini, P .Preti, M. Destro, A. Rinaldi, Gi Derosa, "Effectiveness of Hydrochlorothiazide in combination with Telmisartan and Olmesartan in adults with moderate hypertension not controlled with monotherapy: a prospective, randomized, openlabel, blinded end point (PROBE), parallel-arm study", Curr. Ther. Res., 69 (1), pp. 1-15, 2008.

5) T.W. Littlejohn, C.R. Majul, R.Olvera, M. Seeber, M. Kobe, R.Guthrie, W. Oigman, "Results of rreatment with TelmisartanAmlodipine in hypertensive patients", J. Clin. Hypertens. 11 (4), pp. 207-213, 2009.

6) N. Patel, J.K. Patel, "Analytical methodologies for deter-mination of Telmisartan: an overview", Int. J. Pharm. Pharm. Sci., 5 (1), pp.17-22, 2013.

7) L.I. Bebawy, S.S. Abbas, L.A. Fattah, H.H. Refaat, "Application of firstderivative, ratio derivative spectrophotometry, TLC-densitometry and spectrofluorimetry for the simultaneous determination of Telmisartan and Hydrochlorothiazide in pharmaceutical dosage forms and plasma", II Farmaco, 60 (1), pp. 859-867, 2005.

8) S.V...Londhe, "Stability-indicating HPTLC method for Telmisartan in the presence of degradation products, its process related impurity and identification of acid degradation product", Pharm. Analysis Quality Assur., 2011 (1), pp. 194-211, 2011.

9) C. Prabhu, G.C. Subramanian, A. Karthik, S. Kini, M.S. Rajan, N. Udupa, "Determination of Telmisartan by HPTLC - a stability indicating assay", J. Planar. Chromatogr., 20 (1), pp. 477-481, 2007.

10) C. M. Jamkhandi, J.I. Disouza, D.A. Bhagwat, "Deve-lopment of newer fluorimetric method for estimation of Telmisartan”, Int. J. Pharm. Pharm. Sci., 5 (Suppl 4), 232-233, 2013.

11) M.T. Xu, J.F. Song, Y.D. Liang, "Rapid determination of Telmisartan in pharmaceutical preparations and serum by linear sweep polarography", J. Pharma Biomed. Anal., 34 (3), pp. 681-687, 2004. 
12) N.A. Alarfaj, "Square-wave adsorptive stripping voltam-metric determination of antihyper-tensive agent Telmisartan in tablets and its application to human plasma", Chemistry, 68 (4), pp. 335-340, 2013.

13) H. Taşdemir, M.A. Akay, N. Erk, E. Kılıç, "Voltammetric behavior of Telmisartan and cathodic adsorptive stripping voltammetric method for its sssay in pharmaceutical dosage forms and biological fluids", Electroanalysis, 22 (1718), pp. 2101-2109, 2010.

14) R...Bhaskara, A. L. Rao, "Novel HPLC method development, validation and estimation of Telmisartan in bulk and its pharmaceutical formulation", Int. J. Pharm. Tech. Res., 3 (4), pp. 2001-2005, 2011.

15) S.V. Londhe, N. Kaul, H. Agrawal K.R. Mahadik, "Stability-indicating RP-HPLC method for analysis of Telmisartan in the bulk drug and in formulations", Acta Chromatogr., 22 (4), pp. 539-548, 2010.

16) M.S. Charde, A. Gupta, R.D. Chakole, "Determination of Telmisartan in pharmaceutical formulations by reversed phase high performance liquid chromatography", Int. J. Phytopharm. Res., 2 (2), pp. 61-67, 2012.

17) Gupta, R.M. Charde, M.S. Charde, "Determination of Telmisartan and forced degradation behaviou by RP-HPLC in tablet dosage form”, Int. J. Pharm. Chem., 2 (3), pp. 93-99, 2012.

18) K. Sujana, S.D. Gowri, S.O. Bala, R.G. Swathi, "Stability indicating RP-HPLC method for the determination of Telmisartan in pure and pharmaceutical formulation", Int. J. Pharm. Pharm. Sci., 3 (Suppl 2), pp. 164-167, 2011.

19) S. Nandipati, V.K. Reddy, T.R. Reddy, "Development and validation of RP-HPLC Method for estimation of Telmisartan in bulk and tablet dosage form", Int. Res. J. Pharm. Appl. Sci., 2 (3), pp. 39-43, 2012.

20) M.V. Kumar, P.R. Muley, "Stability indicating RP-HPLC method for determination of Telmisartan in solid dosage forms", Ind. Pharmacist., 4 (36), pp. 69-72, 2005.

21) M.V.B. Rao, A.V.D. Nagendrakumar, M. Sivanadh, G.V. Rao, "Validated of RPHPLC method for the estimation of Telmisartan in tablet formulations", Bull. Pharm. Res., 2 (2), pp. 50-55, 2012.

22) K.K.R. Narendra, G.D. Rao, P.H. Pratyusha, "Isocratic RP-HPLC method validation of telmisartan in pharmaceutical formulation with stress test stability evaluation of drug substance", J. Chem. Pharm. Sci., 5 (1), pp. 16-21, 2012.

23) N.R. Vekariya, G.F. Patel, R.B. Dholakiya, "Determina-tion of Telmisartan in solid dosage form by RPHPLC", Asian J. Res. Chem., 2 (1), pp. 4506-4508, 2009.

24) D. Rao, N.D. Paladugu, B. Satyanarayana, D. Poloju, "Development and validation of RP-HPLC method for the estimation of Telmisartan in bulk drug using internal stadard", Int. J. Res. Pharm. Chem., 3 (3), pp. 650-658, 2013.

25) T.S.R.Bhavani, $\quad$ S.V.N. Raju, B.Madhusudan, J. Begum, "Stability indicating uplc method for the estimation of telmisartan related substances in tablets formulation", Int. J. Sci. Res. Publ., 3 (2), pp. 1-8, 2013.

26) B.R. Patra, S. Mohan, N.Gowda, "Stability-indicating RP-UHPLC method for determination of Telmisartan in drug substance and marketed formulation", Int. J Pharm. Sci. Res., 7 (5), pp. 2031-2039, 2016.

27) S.D. Rathod, P.M. Patil, Waghmare, S.A. Santosh, P.D. Chaudhari, "UVspectrophotometric method for estimaton 
of Telmisartan in bulk and tablet dosage form", Int. J. Pharm. Sci. Res., 3 (10), pp. 3936-3939, 2012.

28) Pandey, H. Sawarkar, M. Singh, P. Kashyap, P. Ghosh, "UVspectrophotometric method for estimation of Telmisartan in bulk and tablet dosage form", Int. J. Chem. Tech. Res., 2011; 3 (2), pp. 657-660.

29) N.D. Chivate, S.M. Patil, J.K. Saboji, A.N.Chivate, "Development of UV spectrophotometric method for estimation and validation of telmisartan as a pure API", J. Pharm. Res., 5 (6), pp. 33313333, 2012.

30) V. Chavhan, R. Lawande, J. Salunke, M. Ghante, S. Jagtap, "UVspectrophotometric method development and validation for Telmisartan in bulk and tablet dosage form", Asian J. Pharm. Clin. Res., 6 (4), pp. 19-21, 2013.

31) R. Jaithlia, R.K. Chouhan, C. Chouhan, A. Gupta, B.P. Nagori, "Development of UV spectrophotometric method and its validation for estimation of telmisartan as API and in Pharmaceutical dosage form", Int. J. Res. Ayurveda Pharm., 2 (6), pp. 1816-1818, 2011.

32) K. K. Pradhan, U. S. Mishra, A. Sahoo, K. C. Sahu, D. Mishra, R. Dash, "Method development and validation of Telmisartan in bulk and pharmaceutical dosage forms by UV spectrophotometric method," Int. J. Res. Pharm. Sci., 2 (4), pp. 526-530, 2011.

33) R.K. Jat, S Sharma, R.C. Chippa, S. Rambir, A. Imran, "Quantitative estimation of Telmisartan in bulk drug and tablets by UV spectroscopy", Int. J. Drug Res. Technol., 2 (3), pp. 268-272, 2012.

34) M.S. Palled, M. Chatter, P. Rajesh, A.R. Bhat, "Difference spectrophotometric determination of Telmi-sartan in tablet dosage forms", Indian J. Pharm .Sci., 68 (5), pp. 685-686, 2006.
35) G.T. Rani， S. Prashanthi， N. Srinivas, "Two simple extractive spectrophotometric methods for the estimation of Telmisartan in pharmaceutical formulation using bromothymol blue and orange - G", Int. J. Pharm. Pharm. Sci., 4 (Suppl 1), pp.382384, 2012.

36) G. Shigari, N.R. Reddy, I.K. Chakravarthi, "Spectropho-tometric determination of Telmisartan sulphate in pharmaceutical dosage forms", Asian J. Pharm. Health Sci., 1 (3), pp.142-144, 2011.

37) S. Bais, C. Singh, I. Singhvi, Y. Joshi, B. Patel, A. Chandewar, "Novel method for quantitative estimation of Telmisartan from tablet formulation by colorimetric method", Asian J. Pharm. Anal., 4 (2), pp. 54-56, 2014.

38) T. Rani, S. Gowri, Madhavi, B. Satyanarayana, "Extractive visible spectrophotometric method for determination of Telmisatan and Irbesartan in bulk and pharmaceutical formulations", Asian J. Pharm. Clin. Res., 5 (1), pp. 41-44, 2012.

39) Z. Qin, W. Niu, R. Tan, "Spectrophotometric method for the determination of Telmisartan with congo red", J. Anal. Chem., 64 (5), pp. 449-454, .2009 .

40) International Conference on Harmonization (1995) guidelines. Validation of ana-lytical procedures: text and methodology Q2 (R1): FDA. Fed. Regist. 60: 11260. 